\title{
Native trees in Nug-as forest Key Biodiversity Area, Cebu, Philippines
}

\author{
EDGARDO P. LILLO ${ }^{1,2, v}$, ARCHIEBALD B. MALAKI ${ }^{1,3, v \vee}$, STEVE MICHAEL T. ALCAZAR ${ }^{3, v,}$ \\ BERNARDO R. REDOBLADO ${ }^{1}$, JOHN LOU B. DIAZ ${ }^{1}$, JUANITA P. PINOTE ${ }^{1}$, RAAMAH ROSALES ${ }^{1, v \vee v, ~}$ \\ INOCENCIO E. BUOT JR $\mathbf{R}^{4, \text { r४ }}$ \\ ${ }^{1}$ Cebu Technological University, Argao Campus. Argao 6021, Cebu, Philippines, `email: lillo_edgardo@yahoo.com ${ }^{\text {}}$ email: epoch7era@gmail.com \\ ${ }^{2}$ Department of Forest Biological Sciences, College of Forestry and Natural Resources, University of the Philippines Los Baños. College Laguna 4031, \\ Laguna, Philippines \\ ${ }^{3}$ School of Environmental Science and Management, University of the Philippines Los Baños. College Laguna 4031, Laguna, Philippines. \\ vemail: archlam68@yahoo.com, alcazarstevemichael@gmail.com \\ ${ }^{4}$ Institute of Biological Sciences, University of the Philippines Los Baños. College Laguna 4031, Laguna, Philippines. Tel: +63-922-8140447, \\ vw»email: iebuot@up.edu.ph
}

Manuscript received: 11 June 2020. Revision accepted: 17 August 2020.

\begin{abstract}
Lillo EP, Malaki AB, Alcazar SMT, Redoblando BR, Diaz JLB, Pinote JP, Rosales R, Buot IE Jr. 2020. Native trees in Nug-as forest Key Biodiversity Area, Cebu, Philippines. Biodiversitas 21: 4162-4167. Threatened species, by definition, have a high probability of extinction, and so each of their populations significantly contributes to their survival. This paper presents a list of threatened Native trees in Nug-as forest of the Municipality of Alcoy, Cebu. A list of indicators was used to identify the conservation status of the Native trees at the local level. A total of 135 native trees from 48 families and 105 genera were recorded. Most species belong to the families of Euphorbiaceae, Lauraceae, Moraceae, Clusiaceae, Myrtaceae, Meliaceae, Fabaceae, and Rutaceae. In this study, 62 species were categorized as threatened, and 72 species as Least Concern, while in IUCN classification 19 threatened species were recorded, and 111 taxa considered as Least Concern respectively. Using the DENR method of classification 15 threatened species were recorded, and 115 taxa considered as Not Evaluated. The Nug-as forest was degraded by illegal cutting, kaingin, hunting and charcoal making. Based from Beynen and Townsend analysis, Nug-as forest was categorized as moderately disturbed. While DENR and IUCN declaration on the status of the Philippine native trees take a very long time, threatened plant species would be gone before we know it, considering the destruction rate in the Philippines.
\end{abstract}

Keywords: Alcoy, disturbance, local conservation status, native trees, threatened species

\section{INTRODUCTION}

The Philippines based on the study of Myers et al. (2000) was considered as one of the 25 megadiverse countries but it also one of the 25 hotspots, and was identified for conservation based on the high number of endemic species and extent of habitat loss in the country. According to Le Roux et al. (2019) distinct temporal patterns, agriculture, invasions, and urbanization being the significant drivers in the loss of biodiversity species. Fortunately, Le Roux et al. (2019) emphasize that plant extinctions over the last three centuries appear to be low, and steady extinction rate of 1.26 extinctions/year. According to WWF (2010), Pakistan has the highest rate of deforestation in Asia with about $2.5 \%$ forest cover and annual $2.1 \%$ deforestation rate. Biodiversity is fundamental for the health of global ecosystems and human well-being (Rands et al. 2010; Brugiere and Scholte 2013). These forest resources have become more important for the people living in or around the forests (Yemiru et al. 2010).

In recent analysis by conservationists, the richness of threatened species was considered as one of the most effective surrogates for the identification and evaluation of conservation priority areas (Myers et al. 2000; Clough et al. 2010; Huang 2011; Neel and Che-Castaldo 2013). Consensus has been reached among the government, academics, and the public that in situ conservation is the most feasible way to conserve biodiversity (Huang 2011; $\mathrm{Wu}$ et al. 2013; Zhang et al. 2015). In fact, Conservation scientists have paid enormous efforts to setting priorities for biodiversity conservation (Trizzino et al. 2015). The global conservation network has also been enhanced to protect biodiversity across the world (Kullberg and Moilanen 2014). Cañadas (2014) emphasized also that the major goal in conservation biology is to determine areas of rich biodiversity.

The Nug-as Forest of the Municipality of Alcoy, Cebu was among the 117 terrestrial areas recognized as one of the Key Biodiversity Areas (KBA). This new KBA site has a total area of 10,457 hectares, and serve as habitat to: two Critically Endangered species, two Endangered species, four Vulnerable species, and 16 Restricted-Range species (CI, DENR, and Haribon 2006). Studying the conservation status of the flora species in the site is important according to Villanueva and Buot (2015), as requirement for conservation action focusing on the species at the greatest risk of extinction.

The two known authorities in red listing threatened plants are the IUCN and the DENR. The most recent evaluation of the threatened status of global biodiversity showed that, 10,896 plant species are threatened, including 2205 Critically Endangered (CR), 3381 Endangered (EN), 
and 5310 Vulnerable (VU) (IUCN 2017). On the other hand, DENR has also its updated national list of threatened plant species and their categories, known as DENR Administrative Order (DAO) No. 2017-11 (DENR 2017). Both the IUCN and the DENR classify a plant as threatened if it falls under the categories Critically Endangered (CR), Endangered (EN), or Vulnerable (VU) and Least Concern (LC).

Despite the existence of IUCN and DENR, local government units still have to have their own local list of endangered species. Local communities are the most knowledgeable concerning the conservation status of species as they are on the ground. They know which species are abundant, and those that are rare, and are at risk of extinction. If a species at risk will not be protected, the local communities will be affected most badly by the deterioration of ecosystem services brought about by the declining population of a concerned species. This is so because they were the ones occupying in the area. Cooperation and awareness of local residence, effective policies can check the degradation of forests (Kibria et al. 2011).

The Department of Environment and Natural Resources- United National Environment Program (DENRUNEP) revealed that there are no known management plans for addressing the plants threat in the Philippines, particularly in Cebu Island, Philippines, where some of the unique fauna and flora exist (i.e., Cinnamomum cebuense, Dicaeum quadricolor, and Vaccinium cebuense (Salares et al. 2018; UNEP 2012).

In this study, a list of threatened trees at the local level was created based on some of the criteria set by Sopsop and Buot (2009). This information is necessary for creating conservation plans and programs for native plants (Hyvärinen et al. 2011), as well as a basis in the formulation of effective policies regarding areas focusing on the conservation of forests (PCARRD 2017; UNEP 2012).

\section{MATERIALS AND METHODS}

The study was conducted in Nug-as forest which was considered as KBA (CI, DENR, and Haribon 2006). It is located in the Municipality of Alcoy, Cebu $\left(9^{\circ} 71^{\prime} \mathrm{N}\right.$, $123^{\circ} 44^{\prime} \mathrm{E}$ ) (Figure 1). The forest has a total area of 1,036 ha, including scrublands and plantations. It is located in the interior portion of the municipality of Alcoy. According to the report of Flora and Fauna International (2012), there were two main types of forests in Nug-as: secondary lowland forest at 200-500 m, and transitional mid-montane forest above $500 \mathrm{~m}$ above sea level.

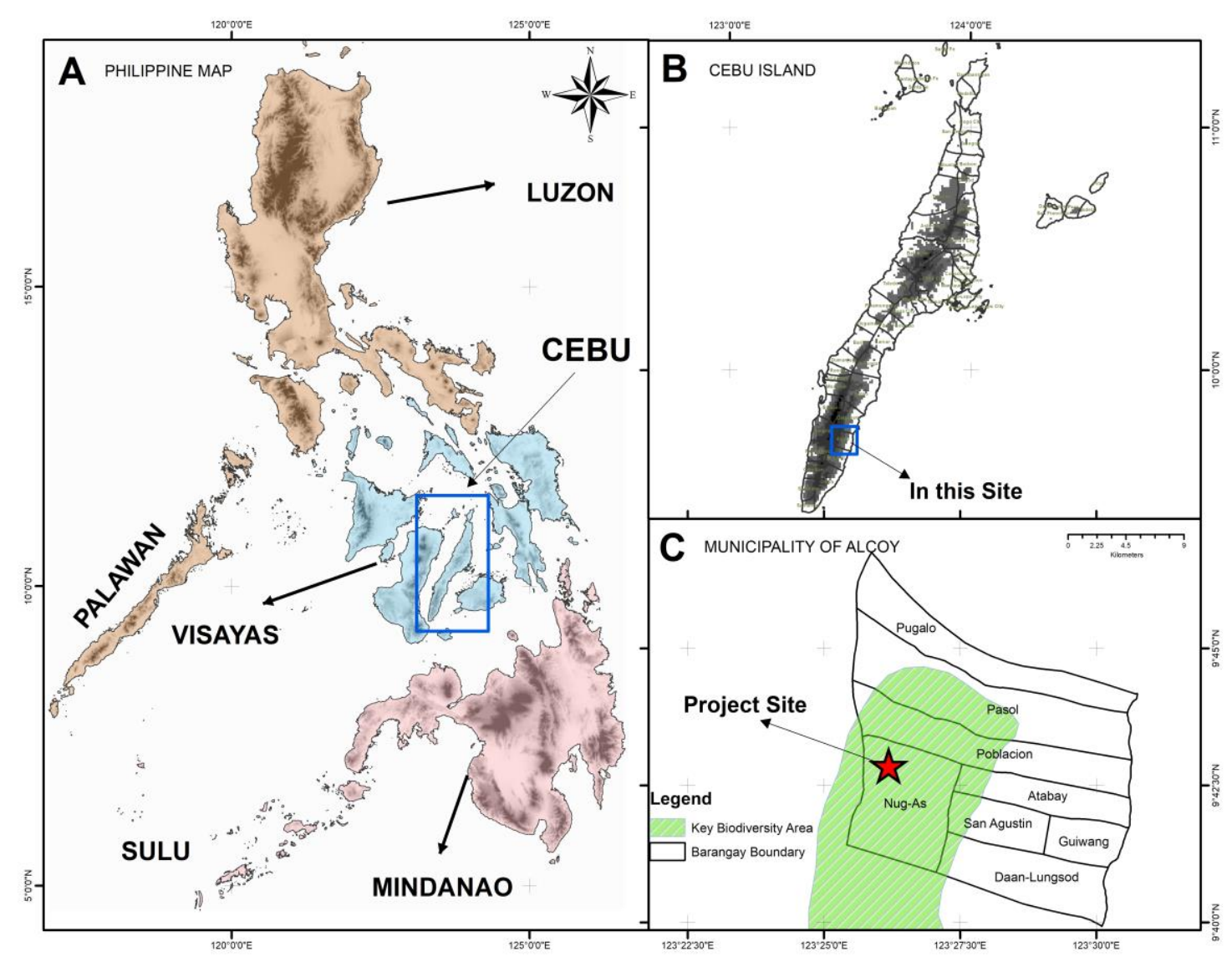

Figure 1. The Philippine map showing Cebu Island, and the study sites and plot locations (GIS generated map; Landsat 8; www.earthexplorer.usgs.ph; NAMRIA; Philippine GIS data) 
Table 1. Modified indicators of the local conservation status of threatened plants by Sopsop and Buot (2009)

\begin{tabular}{|c|c|}
\hline Category & Criteria \\
\hline \multirow{5}{*}{$\begin{array}{l}\text { Critically } \\
\text { Endangered } \\
\text { (CR) }\end{array}$} & Classified as CR either by IUCN (2017) or DENR \\
\hline & \\
\hline & Endemic to Cebu Island \\
\hline & $\begin{array}{l}\text { Thrives in a very rare habitat type (habitat } \\
\text { specialist) }\end{array}$ \\
\hline & $\begin{array}{l}\text { The immediate habitat is extremely threatened by } \\
\text { human settlement and activities like collection, } \\
\text { mining, slash-and-burn or intensive agriculture }\end{array}$ \\
\hline \multirow{4}{*}{$\begin{array}{l}\text { Endangered } \\
(\mathrm{EN})\end{array}$} & $\begin{array}{l}\text { Classified as CR either by IUCN (2017) or DENR } \\
\text { listing (2017) }\end{array}$ \\
\hline & Restricted local distribution within the Cebu area \\
\hline & $\begin{array}{l}\text { The immediate habitat is threatened by human } \\
\text { settlement }\end{array}$ \\
\hline & $\begin{array}{l}\text { Endemic in the Philippines and is threatened due } \\
\text { to collection, mining, slash-and-burn or intensive } \\
\text { agriculture }\end{array}$ \\
\hline \multirow{4}{*}{$\begin{array}{l}\text { Vulnerable } \\
\text { (VU) }\end{array}$} & $\begin{array}{l}\text { Classified as CR either by IUCN (2017) or DENR } \\
\text { listing (2017) }\end{array}$ \\
\hline & Restricted local distribution within the Philippines \\
\hline & The habitat is threatened by human settlement \\
\hline & $\begin{array}{l}\text { Indigenous in the Philippines and is threatened } \\
\text { due to collection, mining, slash-and-burn or } \\
\text { intensive agriculture }\end{array}$ \\
\hline Least & Number of species is more than ten or still \\
\hline $\begin{array}{l}\text { Concern } \\
\text { (LC) }\end{array}$ & abundant in the study site \\
\hline
\end{tabular}

Permanent plots were established in lower (less than $200 \mathrm{~m}$ ) and upper elevation (above $500 \mathrm{~m}$ ) areas of Nug-as forest. The size of the plots was $20 \mathrm{~m}$ x $100 \mathrm{~m}$. A total of eight plots were established in highly stratified vegetation to generate information in all vegetation classes. A vegetation class is usually composed of different strata or layers such as tree canopies, shrub canopies, herbs, and litter (Wang et al. 2001). Coordinates of all the established permanent plots were taken and recorded.

Voucher specimens for every individual of plants within the plots were collected and tagged. The collected specimens were brought to the herbarium laboratory of Cebu Technological University - Argao Campus for proper identification after oven-drying. Identification of sample specimens were done through herbarium comparison (Philippine National Museum file), digital database (Co's Digital Flora of the Philippines; https://www.philippineplants.org), online literature (http://www.theplantlist.org), checklist of Fernando (2007), Lexicon of Philippine tree (Rojo 1999), and the expertise of the project consultants.

All the threatened tree species listed from the KBA were categorized based on three classifying units: IUCN, DENR, and this study. The recorded tree species from the site were compared to the updated list of threatened species issued by DENR Administrative Order (DENR 2017) and also by the Global IUCN Red list.

In this study, the floristic data were then classified as Critically Endangered (CR), Endangered (EN), Vulnerable
(VU), and Least Concern (LC) based on the indicators formulated by Sopsop and Buot (2009) (see Table 1). It is $\mathrm{CR}$ if (1) the number of individuals encountered is five or less, (2) they are found only in a particular area, or (3) their immediate habitat is threatened by a mining concession or kaingin activity, or (4) they are classified as CR either in the IUCN (2017) or DENR (2017) list; It is EN if (1) the number of individuals is five or less per area surveyed, (2) they are found only in a particular area, (3) their immediate habitat is threatened by a mining concession or kaingin activity, or (4) they are classified as EN either in the IUCN (2017) or DENR (2017) list; It is VU if (1) the number of individuals encountered is five to 10 per area, (2) they are found only in a particular area, (3) their habitat is threatened by a mining concession or kaingin activity, or (4) they are VU either in the IUCN (2017) or DENR (2017) list; and LC if the number of species is more than ten or still abundant in the study site (Sopsop and Buot 2009).

The identification and quantification of anthropogenic threats against biodiversity were determined through interviews and direct observation. Direct questions related to threats and disturbance were asked to the randomly selected 60 respondents that live within the vicinity of Nug-as forest KBA, or equivalent to $10 \%$ of the total individuals living in the study site for an occupancy of 20 years and above. This is to ensure that respondents have an overview of the transformation of vegetation of Nug-as Forest due to existing disturbance and threats. These determined disturbance and threat serve as potential hindrances to the existence and survival of threatened tree species in Nug-as Forest KBA. All data collected were tabulated and analyzed based on frequency and its percentage equivalent.

Disturbance and threats impact was determined using the Beynen and Townsend (2006) disturbance index. The scoring system for the disturbance indicators utilized in this study was similar to the model presented by the National Park Conservation Association in their annual assessment of the National Parks of the United States (2004). Each indicator is assigned a score from 0 to 3 based on the evaluator's interpretation of the extent and severity of the variable being considered. A score of 0 means no human impact/karst disturbance. If disturbance is apparent, then the evaluator must judge if the impact is catastrophic (rating $=3$ ), severe and widespread (rating $=2$ ), or localized and not severe (rating = 1) (Beynen and Townsend 2006). Once all the indicators have been scored, scores can be summed. This total is then divided by the highest possible score to attain a value between 0 and 1 . The higher the value i.e., the closer number is to 1 , the greater the degree of disturbance. Five categories have been created and range from 0.8-1.0 (highly disturbed), 0.2-0.79 (moderately disturbed), and 0.0-0.19 (pristine) (Beynen and Towsend 2006).

\section{RESULTS AND DISCUSSION}

A total of 135 tree species recorded from the site. These species were classified into 48 families and 105 genera. 
Based on the conservation status of the species, 62 were categorized as threatened, and 72 species categorized as Least Concern. The result is equivalent to $22 \%$ of the whole Palawan Island with 278 threatened species (Sopsop and Buot 2009), and 36\% to the whole Mindoro Island with 173 threatened plant species (Villanueva and Buot 2015). The result implies for fewer number of threatened native trees in Cebu Island as compared to other islands.

Based on IUCN classification 19 species were considered as threatened, and 107 species categorized as Least Concern (IUCN 2017), while based on DENR classification, 15 species were categorized as threatened, and 115 taxa considered as Least Concern or Not Evaluated. Most of the threatened species belong to the families of Euphorbiaceae, Lauraceae, Moraceae, Clusiaceae, Myrtaceae, Meliaceae, Fabaceae, and Rutaceae. The most common genera were Ficus, Syzygium, and Myrica (Table 2).

The threatened native tree species were classified into $\mathrm{CR}, \mathrm{EN}$, and VU. Out of the 62 threatened plant species listed in this study, 12 were considered as EN, and 50 species were classified as VU (Table 2). In IUCN classification, out of the 19 threatened species, one was considered as CR, three were EN, and 15 were VU (Table 2). In DENR classification (DENR 2017) out of 15 threatened species, two were considered as CR, two EN, and 11 were VU (Table 2).

The species of Cinnamomum cebuense Kosterm was categorized as Endangered in this study, as well as in DAO (DENR 2017), but categorized as Critically Endangered in IUCN (IUCN 2017). As observed in the area, the number of individuals for Cinnamomum cebuense Kosterm was increasing. According to the people of Nug-as, Alcoy, Cebu during the informal interview conducted, the species were protected and conserved per order of the Municipal Environment and Natural Resources Office (MENRO) of the Municipality of Alcoy, Cebu. Aside from that, five mother trees with an average diameter of $30 \mathrm{~cm}$ were observed in the site. The existence of seedlings and saplings of the species near the mother trees served as proof that the species were conserved and properly protected by the people of Nug-as, Alcoy.

In this study, 12 species of trees were also categorized as Endangered because its number of individuals was already less than 5 as could be observed in the field. This result complements the record of both IUCN and DENR (Table 2). Consequently, 50 species of trees were also recorded and categorized as Vulnerable in this study, its number was greater as compared to IUCN and DENR record (Table 2). Based on the non-formal interviews conducted from the community, the number of individuals of this species was already less than 10. In Table 2, the number of Vulnerable species recorded in DENR differs from IUCN. These differences according to Villanueva and Buot (2015) was affected by the area and species priority of each agency. However, $53 \%$ of the species in this study were categorized as Least Concern (LC) (Table 2). Least Concern means the species were still abundant or their number based on individual records is still more than 10 (Table 1).
Table 2. Threatened native tree species in Nug-as forest KBA

\begin{tabular}{lccc}
\hline Category & \multicolumn{3}{c}{ Classifying unit } \\
\cline { 2 - 4 } & IUCN & DENR & This study \\
\hline Critically Endangered (CR) & 1 & 2 & 0 \\
Endangered (EN) & 3 & 2 & 12 \\
Vulnerable (VU) & 15 & 11 & 50 \\
Least Concern (LC) & 107 & 115 & 72 \\
\hline
\end{tabular}

Table 3. Ranking of forest degradation and the Beynen and Townsend (2006) Disturbance value

\begin{tabular}{|c|c|c|c|c|}
\hline $\begin{array}{l}\text { Causes of forest } \\
\text { degradation in } \\
\text { Nug-as forest KBA }\end{array}$ & Respondents & $\%$ & Ranking & $\begin{array}{l}\text { Beynen and } \\
\text { Townsend } 2006 \\
\text { (scoring) }\end{array}$ \\
\hline Illegal cutting & 24 & 55 & 1 & 2 \\
\hline Kaingin activity & 17 & 37 & 2 & 3 \\
\hline Illegal hunting & 13 & 30 & 3 & 3 \\
\hline Charcoal making & 9 & 20 & 4 & 3 \\
\hline Fuelwood & 8 & 18 & 5 & 1 \\
\hline $\begin{array}{l}\text { Other (causes not } \\
\text { mentioned above) }\end{array}$ & 4 & 9 & 6 & 2 \\
\hline Score & \multicolumn{4}{|c|}{0.78} \\
\hline Disturbance value & & & \multicolumn{2}{|c|}{ Moderately disturbed } \\
\hline
\end{tabular}

Note: Respondents were required to enumerate more than one causes of forest degradation

Localized surveys could give regular updates on the number of individuals on a certain species particularly those species that were already threatened because it requires only less budget. IUCN (2017) and DENR (2017) has less number of recorded threatened species (Table 2) because these two organization has a difficulty of updating their records regularly. This problem commonly arises from an organization which has large area of coverage. Currently, the DENR has already released its latest listing of threatening plants species in the Philippines for 2017 (DENR 2017). This updated DENR listing of threatened species is a favorable instrument to be used as one of the legal bases whether to deny or approve development projects in the area which serve as habitat of such species (Sopsop and Buot 2009). IUCN has also developed its own red list of threatened species as tool to help organize biodiversity conservation programs.

Primarily as observed by and based on the respondents perception, Nug-as forest KBA experienced a rapid deterioration of its forest stocks, caused by illegal cutting, Kaingin (rampant conversion of forests to agriculture), and hunting (Table 3). The result of the study conformed to the findings of DENR, Conservation International, and Haribon (2006) that Nug-as and Mount Lantoy KBA were degraded due to illegal logging, human encroachment, and land conversion.

Based on the Beynen and Townsend (2006) scoring system, Nug-as forest KBA is moderately disturbed (Table $3)$. The rate of disturbance was the same with Mount Lantoy KBA which is also moderately disturbed (Lillo et al. 2019) (Table 3). The Moderately disturbed areas imply that disturbance and threats in the forest were still in a minimal effect to tree species diversity. According to 
Willby et al. (2001), and Weithoff (2003) moderate disturbance intensity, demonstrates maximized functional diversity. Furthermore, Nug-as KBA was still rich in native tree species based on our observation in the study site. However, we could not deny that deterioration of native trees alters the life of all biodiversity in the environment, as well as of the people in the community within the vicinity and surrounding of Nug-as forest KBA. According to Sopsop and Buot (2009), changes in the natural condition of the forest induce threats to native plant species. The conceptual linkages between ecosystem disturbance, species diversity, and functional diversity are fundamental to resource management and conservation planning (Diaz et al. 2007).

\section{ACKNOWLEDGEMENTS}

The authors would like to acknowledge the Department of Science and Technology (DOST), Philippines for considering and approving our research proposal and giving us the budget for three years enough for the implementation of the whole study, and declaring CTU as one of the DOST-Biodiversity Centers through the NICER program in Region 7. The Philippine Council for Agriculture and Aquatic Resources Research Development (PCAARRD) for recommending our proposal to DOST for approval and guide us in the implementation of the study, assisted us in the report preparation, and writing. The CTU System for supporting the research team and allowing the research staff and forestry students to conduct the study. The CENRO Argao for approving our request to conduct the study in different KBAs.

\section{REFERENCES}

Beynen PV, Townsend K. 2006. A disturbance index for kars environments. Environ Manag 36 (1): 101-116.

Brugiere D, Scholte P. 2013. Biodiversity gap analysis of the protected area system in poorly-documented. Chad J Nat Conserv 21: 286-293.

Cañadas EM, Fenu G, Peñas J, Lorite J, Mattana E, Bacchetta G. 2014 Hotspots within hotspots: Endemic plant richness, environmental drivers, and implications for conservation. Biol Conser 170: 282-291.

Clough Y, Abrahamczyk S, Adams MO, Anshary A, Ariyanti N, Betz L, Buchori D, Cicuzza D, Darras K, Putra DD, Fiala B, Gradstein SR, Kessler M, Klein AM, Pitopang R, Sahari, B, Scherber C, Schulze $\mathrm{CH}$, Shahabuddin Sporn S, Stenchly K, Tjitrosoedirdjo SS, Wanger, TC, Weist M, Wielgoss A, Tscharntke T. 2010. Biodiversity patterns and trophic interactions in human-dominated tropical landscapes in Sulawesi (Indonesia): plants, arthropods, and vertebrates. In Tscharntke T, Leuschner C, Veldkamp E, Faust H, Guhardja E, Bidin A. (eds.). Tropical Rainforests and Agroforests Under Global Change. Environmental Science and Engineering (Environmental Engineering). Springer, Berlin. DOI 10.1007/978-3-642-00493-3_2,

Conservation International Philippines (CI), Department of Environment and Natural Resources - Protected Areas and Wildlife Bureau (DENR-PAWB), Haribon Foundation for the Conservation of Nature (HARIBON). 2006. Priority Sites for Conservation in the Philippines: Key Biodiversity Areas. Conservation International Philippines. Quezon City, Philippines. http://www.conservation.org/global/philippines/publications/Pages/Pr iority-Sites-for-Conservation-Key-Biodiversity-Areas.aspx.

DENR. 2017. Updated National List of Threatened Philippine Plants and their Categories. Department of Environment and Natural Resources, Philippines.
Diaz S, Lavorel S, de Bello F, Quetier F, Grigulis K, Robson TM. 2007. Incorporating plant functional diversity effects in ecosystem service assessments. Proc Natl Acad Sci USA 104 (52): 20684-20689.

Fernando ES. 2007. Checklist of Species in FBS 21 (Taxonomy of Forest Plants), 2007. 12th ed. University of the Philippines, Los Baños.

Flora and Fauna International. 2012. Final report. Biodiversity assessment in the Key Biodiversity Areas of the Southern part of Cebu Island. Philippine.

Huang H. 2011. Plant diversity and conservation in China: planning a strategic bioresource for a sustainable future. Bot J Linn Soc 166 (3): 282-300.

Hyvärinen M, Miranto M, Hiltunen R, Schulman L. 2011. Strategy and action plan for ex-situ conservation of threatened plants in FinlandAction 11: assessment of the impacts of climate change on biodiversity in coastal ecosystems and the implementation of new policies and conservation strategies. www.ymparisto.fi/download .asp? contentid=132157\&lan=fi

IUCN 2017. International Union for Conservation of Nature. IUCN updates 'red list' of endangered species. https://www.iucn.nl/en/solutions/red-list-of-threatened-species.

Kibria MG, Rahman SA, Imtiaj A, Suderland T. 2011. Extent and consequences of tropical forest degradation: Successive policy options for Bangladesh. J Agric Sci Technol B 1 (1): 29-37.

Kullberg P, Moilanen A. 2014. How do recent spatial biodiversity analyses support the convention on biological diversity in the expansion of the global conservation area network? Nat Conserv 12: 3-10.

Le Roux JL, Hui C, Castillo ML, Theron G, Yannelli FA, Hirsch H. 2019. Recent anthropogenic plant extinctions differ in biodiversity hotspots and coldspots. Curr Biol 29 (17): 2775-2972.

Lillo EP, Malaki ABB, Alcazar SMT, Nuevo RU, Rosales R. 2019. Native trees on Mount Lantoy Key Biodiversity Areas (KBA), Argao, Cebu, Philippines. Philippine J Sci 148 (2): 359-371.

Myers N, Mittermeier RA, Mittermeier CG, Fonesca GAB, Kent J. 2000. Biodiversity hotspots for conservation priorities. Nature 403 (24): 853-858.

Nations J. 2004. State of the parks. Fort Collins, CO: National Parks Conservation Association. http://www.npca.org/across_the_nation/park_pulse/about/default.asp

Neel MC, Che-Castaldo JP. 2013. Predicting recovery criteria for threatened and endangered plant species on the basis of past abundances and biological traits. Conserv Biol 27: 385-397.

PCARRD. 2017. Manual on vegetational analysis for grassland and forest ecosystems. Philippine Council for Agriculture, Forestry and Natural Resources Research and Development. Department of Science and Technology, Los Baños.

Rands MR, Adams WM, Bennun L, Butchart SH, Clements A, Coomes D, Entwistle A, Hodge, I, Kapos V, and Scharlemann JP. 2010. Biodiversity conservation: challenges beyond 2010. Science 329: 1298-1303.

Rojo JP. 1999. Revised lexicon of Philippine trees. www.worldcat.org/title/revised-lexicon-of-philippinetrees/oclc/44890100

Salares VB. Obico JJ A, Ormerod P. Barcelona JF, Pelser P B. 2018. Taxonomic novelties from Cebu: a new species of Vaccinium (Ericaceae) and a new record of Phaius (Orchidaceae) for the Philippines. Phytotaxa 360 (3): 255-262.

Sopsop LB, Buot IE Jr. 2009. The endangered plants of Palawan Island, Philippines. Asia Life Sci 18 (2): 251-279.

The Plantlist. 2020. The Plant List of all known plant species. http:/ /www.theplantlist.org/1.1/about/.

Trizzino M, Bisi F, Maiorano L, Martinoli A, Petitta M, Preatoni DG, Audisio P. 2015. Mapping biodiversity hotspots and conservation priorities for the Euro-Mediterranean headwater ecosystems, as inferred from diversity and distribution of a water beetle lineage. Biodivers Conserv 24: 149-170.

UNEP. 2012. Green Economy Advisory Services. United National Environment Program, Philippines.

Villanueva ELC, Buot IE Jr. 2015. Threatened plant species of Mindoro, Philippines. IAMURE Intl J Ecol Conserv 14: 168 -189.

Wang H, Liu G, Q Wang Q. 2001. Structural characteristics of effective vegetation for preventing soil erosion. Chin J Eco-agric 9 (2): 54-56.

Weithoff G. 2003. The concepts of "plant functional types" and "functional diversity" in lake phytoplankton: a new understanding of phytoplankton ecology? Freshw Biol 48: 1669-1675. 
Willby NJ, Pygott JR, Eaton W. 2001. Inter-relationships between standing crop, biodiversity and trait attributes of hydrophytic vegetation in artificial waterways. Freshw Biol 46: 883-902.

WWF. 2010. Living Planet Report. World Wide Fund, Nederlands. http://www.footprintnetwork.org/press/LPR2010.pdf.

Wu QM, Wang WF, Xu TL, Xu K, Wang XC, Xu XJ, Zou HF. 2013. Conservation practice of artificial breeding red-crowned crane in Zhalong Nature Reserve, China. China J Zool 48: 712-716.
Yemiru T, Roos A, Campbell BM, Bohlin F. 2010. Forest incomes and poverty alleviation under participatory forest management in Bale Highlands, Southern Ethiopia. Intl For Rev 12 (1): 66-77.

Zhang ZJ, Yan YJ, Tian Y, Li JS, He JS, Tang ZY. 2015. Distribution and conservation of orchid species richness in China. Biol Conserv 181: 64-72. 